\title{
Key processes in the coupled carbon, nitrogen, and phosphorus cycling of the Baltic Sea
}

\author{
Erik Gustafsson (D) O Oleg P. Savchuk • Bo G. Gustafsson • Bärbel Müller-Karulis
}

Received: 28 February 2017 / Accepted: 2 July 2017 / Published online: 31 July 2017

(C) The Author(s) 2017. This article is an open access publication

\begin{abstract}
In this study we examine pools of carbon $(\mathrm{C})$, nitrogen $(\mathrm{N})$, and phosphorus $(\mathrm{P})$ in the Baltic Sea, both simulated and reconstructed from observations. We further quantify key fluxes in the $\mathrm{C}, \mathrm{N}$, and $\mathrm{P}$ cycling. Our calculations include pelagic reservoirs as well as the storage in the active sediment layer, which allows a complete coverage of the overall $\mathrm{C}, \mathrm{N}$, and $\mathrm{P}$ cycling on a system-scale. A striking property of $\mathrm{C}$ versus $\mathrm{N}$ and $\mathrm{P}$ cycling is that while the external supplies of total $\mathrm{N}$ and $\mathrm{P}$ (TN and TP) are largely balanced by internal removal processes, the total carbon (TC) supply is mainly compensated by a net export out of the system. In other words, external inputs of $\mathrm{TN}$ and $\mathrm{TP}$ are, in contrast to $\mathrm{TC}$, rather efficiently filtered within the Baltic Sea. Further, there is a net export of TN and TP out of the system, but a net import of dissolved inorganic $\mathrm{N}$ and $\mathrm{P}$ (DIN and DIP). There is on the contrary a net export of both the organic and inorganic fractions of TC. While the pelagic pools of $\mathrm{TC}$ and $\mathrm{TP}$ are dominated by
\end{abstract}

Responsible Editor: Maren Voss.

Electronic supplementary material The online version of this article (doi:10.1007/s10533-017-0361-6) contains supplementary material, which is available to authorized users.

E. Gustafsson $(\bowtie) \cdot$ O. P. Savchuk .

B. G. Gustafsson · B. Müller-Karulis

Baltic Nest Institute, Baltic Sea Centre, Stockholm

University, 10691 Stockholm, Sweden

e-mail: erik.gustafsson@su.se inorganic compounds, TN largely consists of organic $\mathrm{N}$ because allochthonous organic $\mathrm{N}$ is poorly degradable. There are however large basin-wise differences in $\mathrm{C}, \mathrm{N}$, and $\mathrm{P}$ elemental ratios as well as in inorganic versus organic fractions. These differences reflect both the differing ratios in external loads and differing oxygen conditions determining the redox-dependent fluxes of DIN and DIP.

Keywords Baltic Sea · Modelling · Oceanography · Biogeochemistry $\cdot$ Carbon cycling $\cdot$ Nutrient cycling

\section{Introduction}

Coastal seas such as the Baltic (Fig. 1) are in terms of productivity and oxygen conditions heavily influenced by external sources of inorganic and organic $\mathrm{C}, \mathrm{N}$, and P. Internal pelagic and benthic processes such as primary production and mineralization of organic material drive transformations between inorganic and organic pools, and further transports between sedimentary, marine, and atmospheric reservoirs. Particularly important for the cycling of $\mathrm{N}$ and $\mathrm{P}$ (and to a lesser extent $\mathrm{C}$ ) in the Baltic Sea are redox alterations of biogeochemical processes (e.g. Conley et al. 2009; Savchuk 2010). Eutrophication has caused expanding areas suffering from critically low or even depleted oxygen levels in many coastal ecosystems-not least in the Baltic Sea which is considered to have the largest man-made dead zones in the world (Diaz and 


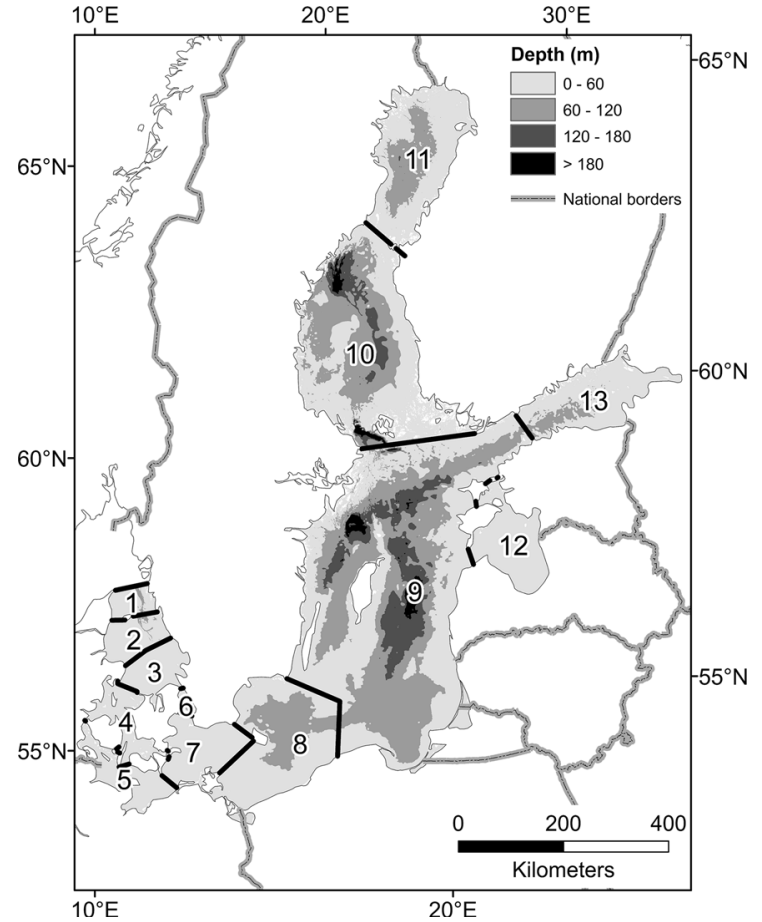

Fig. 1 Map over the Baltic Sea area, indicating the thirteen BALTSEM sub-basins; 1 Northern Kattegat (NK), 2 Central Kattegat (CK), 3 Southern Kattegat (SK), 4 Sams $\varnothing$ Belt (SB), 5 Fehmarn Belt (FB), 6 Öresund (OS), 7 Arkona Basin (AR), 8 Bornholm Basin (BN), 9 Gotland Sea (GS), 10 Bothnian Sea (BS), 11 Bothnian Bay (BB), 12 Gulf of Riga (GR), 13 Gulf of Finland (GF)

Rosenberg 2008). Deoxygenation tends to reduce overall DIN levels in the water column (e.g. Savchuk 2010), whereas the effect on pelagic DIP levels is the opposite (e.g. Conley et al. 2002).

Following oxygen depletion, other oxidants than oxygen (i.e. nitrate, manganese- and iron oxides, and sulfate) are used to oxidize/mineralize organic material. DIN can be transformed into dinitrogen gas $\left(\mathrm{N}_{2}\right)$ through denitrification and/or anammox. This $\mathrm{N}_{2}$ production represents a net loss from the DIN and TN reservoirs as $\mathrm{N}_{2}$ is not included in these pools either by definition or determination methods. DIP-P can during oxic conditions be bound into particulate iron-humic complexes both in the water column and sediments, while during anoxic conditions iron oxides are reduced and DIP is released into the water column. Thus, large-scale deoxygenation has the effect that $\mathrm{P}$ is less efficiently retained in the sediments, and the pelagic DIP concentrations then tend to increase. Removal of DIN due to denitrification and anammox in combination with a release of accumulated DIP from anoxic bottoms lead to favorable conditions for $\mathrm{N}_{2}$ fixing cyanobacteria (e.g. Vahtera et al. 2007). $\mathrm{N}_{2}$ fixation represents an important additional $\mathrm{N}$ source as shown by both measurements and model simulations.

Dissolved inorganic carbon (DIC) concentrations in the surface layer are adjusted by $\mathrm{CO}_{2}$ assimilation and respiration, and further by $\mathrm{CO}_{2}$ fluxes between air and water as the partial pressure of $\mathrm{CO}_{2}\left(\mathrm{pCO}_{2}\right)$ in surface waters tends to equilibrate with $\mathrm{pCO}_{2}$ in the air. The $\mathrm{CO}_{2}$ buffering capacity is controlled by the total alkalinity (TA) concentration. Deteriorating oxygen conditions results in increasing fractions of organic material being mineralized anaerobically. Anaerobic mineralization in general results in a TA generation (for example as a result of denitrification) that can enhance the buffering capacity for $\mathrm{CO}_{2}$ in the water column and increase the absorption of atmospheric $\mathrm{CO}_{2}$ (or decrease $\mathrm{CO}_{2}$ outgassing) (e.g. Thomas et al. 2009).

Eutrophication can be understood as a misbalance between in- and outputs (sources and sinks) of nutrients (e.g. Savchuk 1986, 2002), leading to increased accumulation of organic matter in aquatic systems (e.g. Nixon 1995). At system level, eutrophication is thus determined by nutrient pools and their biogeochemical fluxes. These pools and fluxes should be particularly reliably described by models. Therefore, one of the most important model validation criteria is to compare simulated pools and fluxes with values derived from observations within the budgeting approach. One major point of large-scale and longterm budget calculations is to determine key carbon and nutrient fluxes on a basin-scale or even systemscale. These fluxes together with carbon and nutrients stocks can then for example be used to estimate residence times in the system. Besides, budgets are also a very important and convenient tool for interdisciplinary communications and presentation of results to the general public and stakeholders (Savchuk and Wulff 2007).

Earlier Baltic Sea nutrient budget studies have included observed TN and TP (Savchuk 2005 and references therein), as well as simulated DIN, DIP, and dissolved silica (Savchuk and Wulff 2009). In this study we calculate $\mathrm{C}, \mathrm{N}$, and $\mathrm{P}$ budgets using the physical-biogeochemical BALTSEM model. The present version of BALTSEM (cf. Gustafsson et al. 2014a) explicitly includes DIC, DIN, and DIP, as well 
as dissolved and particulate organic $\mathrm{C}, \mathrm{N}$, and $\mathrm{P}$, allowing separate budget calculations for organic, inorganic, and total $\mathrm{C}, \mathrm{N}$, and $\mathrm{P}$ pools and fluxes. Our calculations include pelagic pools and their transformations as well as storage and transformations in the active sediment layer, which allows a complete coverage of the overall $\mathrm{C}, \mathrm{N}$, and $\mathrm{P}$ cycling.

The main objectives of this study are (i) to validate model results by use of basin-wide pools and average concentrations of $\mathrm{N}$ and $\mathrm{P}$ reconstructed from observations, and (ii) to quantify key $\mathrm{C}, \mathrm{N}$, and $\mathrm{P}$ fluxes, i.e., the external loads, internal source and sink terms, transports between basins, and export out of the system. Further, (iii) we describe and discuss similarities and differences between cycling of $\mathrm{C}, \mathrm{N}$, and $\mathrm{P}$ at system level. Validation data and a description of the BALTSEM model are presented in "Materials and methods" section. Results are presented and discussed in "Results and discussion" section. Our main findings are summarized in "Summary and conclusions" section.

\section{Materials and methods}

Oceanographic data

Integrated basin-wide annual mean concentrations and pools of TN, TP, DIN, and DIP used for BALTSEM validation were computed on $3 \mathrm{D}$ gridded fields reconstructed from observations by the Data Assimilation System (DAS; Sokolov et al. 1997) for the time-period 1970-2014. The data for reconstruction have been extracted from the Baltic Environmental Database (BED) and a system of distributed databases maintained by Finland, Denmark, Germany, and Sweden (http://nest.su.se/bed/). A detailed description of the procedure, including consideration of peculiarities, limitations, and uncertainties is available in Savchuk (2010).

\section{Model description}

BALTSEM is a coupled physical-biogeochemical model that divides the Baltic Sea into thirteen connected sub-basins (Fig. 1). Each sub-basin is described as horizontally homogeneous although with high vertical resolution and. The horizontal areas at different water depths are based on real hypsography of the various subbasins of the system. Mixing and advection is simulated in a hydrodynamic module (Gustafsson 2000, 2003), while the dynamics of nutrients and plankton (Savchuk 2002; Gustafsson et al. 2012; Savchuk et al. 2012) as well as organic carbon and the carbonate system processes (Gustafsson et al. 2014a, b, 2015) are simulated in a biogeochemical module.

Nitrogen is represented by ammonium, nitrate + nitrite, refractory and labile fractions of dissolved organic nitrogen (DON), and detrital particulate organic nitrogen (PON). The ammonium and nitrate + nitrite concentrations together comprise the DIN pool. Phosphorus is represented by DIP, refractory and labile fractions of dissolved organic phosphorus (DOP), and detrital particulate organic phosphorus (POP). Carbon is represented by DIC, dissolved organic carbon (DOC), and detrital particulate organic carbon (POC). In addition, the $\mathrm{C}, \mathrm{N}$, and $\mathrm{P}$ contents of autotrophs and heterotrophs contribute to the pelagic pools of POC, PON, and POP. Total organic $\mathrm{C}, \mathrm{N}$, and $\mathrm{P}$ (TOC, TON, and TOP) represent the sums of dissolved and particulate organic $\mathrm{C}, \mathrm{N}$, and $P$ respectively.

DOC in the model is distributed between four individual state variables, allowing a separation between marine and terrestrial DOC, and further between refractory and labile fractions (Gustafsson et al. 2014a). The separation between marine and terrestrial fractions is for consistency also applied to POC in the water column as well as organic carbon in the active sediment layer. The separation is made for comprehensive tracing of the pathways of terrestrial organic carbon in the model.

$\mathrm{C}, \mathrm{N}$, and $\mathrm{P}$ accumulate in the sediments via sedimentation of particles to the simulated active sediment layer. This layer undergoes transformations in form of mineralization and downward transport (representing resuspension and resettling) of organic matter. A fraction of the material in the active layer is mineralized and released to the water column, while a small share is permanently lost through burial. For DIN and DIP, the sediment-to-water fluxes are modified by denitrification/anammox and $\mathrm{P}$ sequestration respectively. Denitrification and anammox related fluxes are not calculated separately in the model. Instead, the overall nitrate/nitrite losses related to sedimentary mineralization processes are controlled by oxygen conditions in the overlying water column: Under anaerobic conditions all of the mineralized nitrogen is released to the water colomn as 
ammonium, while under aerobic conditions one fraction of the nitrite and nitrate that was produced by mineralization and nitrification is released to the water column ands the remaining fraction is removed by denitrification (Savchuk et al. 2012). As denitrification seems to be far more important than anammox in the Baltic Sea (e.g. Bonaglia et al. 2016), we shall henceforth refer to nitrate/nitrite losses as denitrification, although in reality the losses result from a combination of denitrification and anammox.

DIP fluxes between the sediment surface and water column are controlled by oxygen concentration and salinity (e.g. Savchuk et al. 2012). Reciprocal salinity as an indicator of freshwater conditions is used here as a proxy of the available iron and humic substances that in oxic conditions bind inorganic $\mathrm{P}$ in particulate complexes. If oxygen reaches critically low concentrations in the water column, DIP-P is rapidly released from underlying sediments due to dissolution of ironhumic P-binding complexes. Sediments underlying oxic water are in contrast able to adsorb DIP-P from the water column through precipitation and storage of $\mathrm{P}$ bound by iron-humic complexation.

Based on budget calculations, Gustafsson et al. (2014b) demonstrated that external sources of TA based on available observations together with internal TA sources cacluted in the BALTSEM model are not sufficient reporoduce observed TA concentrations in the system. Unresolved additional TA sources were for that reason calibrated for the different sub-basins in the system. These unresolved sources are used in this study as well.

\section{Simulation setup}

In the present study, the model run covers the period 1970-2014. The model is forced by meteorological data with a 3-h resolution. The meteorological data include wind speed, air temperature, relative humidity, cloudiness, air pressure, and precipitation. In addition, daily average sea level in the Kattegat as well as daily profiles of all state variables at the Skagerrak boundary are required. Monthly runoff data as well as river loads and atmospheric depositions are needed as well.

Model forcing for BALTSEM covers the period 1850-2014. Historical forcing data, covering the period 1850-2006, have been described in detail by Gustafsson et al. (2012). In addition, meteorological forcing files covering the period 1999-2014 were computed from MESAN data downloaded from databases provided by the Swedish Meteorological and Hydrological Institute (SMHI). The Kattegat water level was updated to December 2014 using data provided by the SMHI. Based on Pollution Load Compilation (PLC) data (HELCOM 2013) river runoff and nutrient loads have been updated to 2012. Data for 2013-2014 were not available, so for that reason the monthly loads from 2012 were repeated in the years 2013-2014.

River loads of DIC, DOC and TA are in contrast based only on available observations in 1996-2000 (cf. Gustafsson et al. 2014b). These observations have been used to compute average concentrations of DIC, DOC and TA in river water entering different subbasins of the system. Based on Stepanauskas et al. (2002), the river loads of particulate organic carbon (POC) were assumed to be equal to the PON load multiplied by the $\mathrm{C}: \mathrm{N}$ ratio for particulate organic matter in river water. The atmospheric deposition of DOC has been assumed to be constant throughout the study period and based on Anttila et al. (1995) amounts to $1 \mathrm{~g} \mathrm{C} \mathrm{m}^{-2}$ year $^{-1}$.

Exchange of $\mathrm{CO}_{2}$ between air and sea is controlled by the air-water difference in $\mathrm{pCO}_{2}$ and by the wind speed dependent transfer velocity. Following Wanninkhof et al. (2009), the exchange $\left(F_{\mathrm{CO}_{2}}\right)$ is computed as:

$F_{\mathrm{CO}_{2}}=k_{w \mathrm{CO}_{2}} K_{0}\left(p \mathrm{CO}_{2 w}-p \mathrm{CO}_{2 a}\right)$

The transfer velocity, $k_{w \mathrm{CO}_{2}}$, is computed according to Weiss et al. (2007):

$k_{w \mathrm{CO}_{2}}=k(660 / S c)^{0.5}$

The parameterization for normalized transfer velocity, $\mathrm{k}$, follows Wanninkhof et al. (2009):

$k=3+0.1 W+0.064 W^{2}+0.011 W^{3}$

In the expressions above, $\mathrm{K}_{0}$ is the $\mathrm{CO}_{2}$ gas solubility (Weiss 1974); $\mathrm{pCO}_{2 \mathrm{w}}$ and $\mathrm{pCO}_{2 \mathrm{a}}$ indicate $\mathrm{pCO}_{2}$ in surface water and air respectively; $\mathrm{Sc}$ is a temperature-dependent Schmidt number (Wanninkhof 1992); W is wind speed.

\section{Basins}

To construct carbon and nutrient budgets we aggregated some BALTSEM sub-basins into larger units: 
The Kattegat (KT) includes sub-basin 1-3, the Danish Straits (DS) includes sub-basin 4-6, the Baltic Proper (BP) includes sub-basin 7-9, and the Entire Baltic Sea (EBS) includes all sub-basins (Fig. 1). Areas and volumes of these basins are presented in Table S1 (supporting information).

\section{Results and discussion}

Pools and ratios

Basin-wide volume weighted mean annual concentrations of DIN, DIP, TN, and TP were calculated based on both model output and observations. Comparisons between time-series of model-based and measurement-based values were performed for the EBS (Fig. 2) as well as for seven basins (the Kattegat (Fig. S1), Danish Straits (Fig. S2), Baltic Proper (Fig. S3), Bothnian Sea (BS; Fig. S4), Bothnian Bay (BB; Fig. S5), Gulf of Riga (GR; Fig. S6), and Gulf of Finland (GF; Fig. S7) respectively (cf. Fig. 1)). Average simulated versus observed concentrations of TN, TP, TON, TOP, DIN, and DIP in 1980-2014 are presented in Tables 1 and 2 (the period 1970-1979 was excluded from the comparison because of gaps and uncertainties in the observed values).

For N, the simulated TN concentration in EBS is somewhat higher than observed. This is a result of overestimated TON in BP and BS (the largest basins in the system; cf. Table S1). Simulated DIN is on the other hand underestimated in the entrance area (KT and DS) as well as in BP, but overestimated in the gulfs (BS, BB, GR, and GF). The simulated $\mathrm{P}$ concentrations in EBS are close to observed values. However, we find overestimated simulated DIP in the gulfs but underestimated in the entrance area and BP (similar to DIN).

The availability of DIC observations is rather limited in most basins, and observed DOC and/or TOC concentrations are mostly unavailable with required resolution. For that reason we have no estimates of basin-wide mean $\mathrm{C}$ concentrations based on observations. Simulated organic and inorganic carbon concentrations have however been validated in earlier publications (Gustafsson et al. 2014a, 2015), and average basin-wide simulated concentrations of TC, TOC, and DIC are presented in Table 3.

Basin-wise differences in DIC concentrations are partly related to salinity; the higher the salinity, the
Fig. 2 Average observed (circles) and simulated (full lines) volume weighted annual mean concentrations of DIN, DIP, TN, and TP $(\mu \mathrm{M})$ in the entire Baltic Sea; open circles indicate years with data available in all sub-basins, while full circles indicate concentrations estimated by first replacing missing values in individual subbasins (cf. Figs. S1-S7) by their long-term mean concentrations, and then calculating overall mean concentrations for the entire Baltic Sea
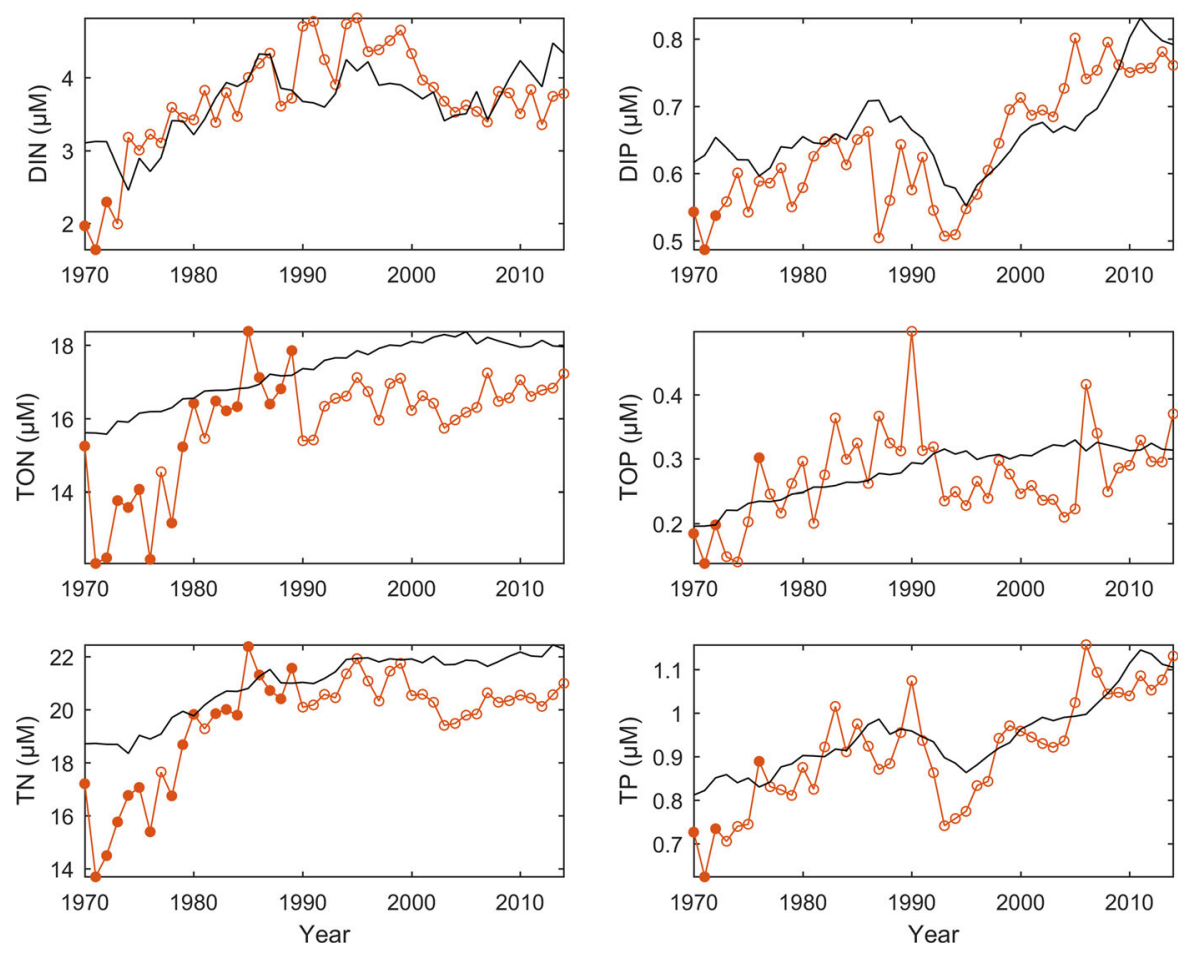
Table 1 Average simulated and observed 1980-2014, as well as the difference between simulated and observed concentrations calculated as $100 \times($ sim-obs $) /$ obs $(\%)$ (basins according to Fig. 1) pelagic $\mathrm{N}(\mu \mathrm{M})$ in

\begin{tabular}{|c|c|c|c|c|c|c|c|c|c|}
\hline & \multicolumn{3}{|l|}{$\mathrm{TN}$} & \multicolumn{3}{|c|}{ TON } & \multicolumn{3}{|l|}{ DIN } \\
\hline & Sim & Obs & Diff $(\%)$ & Sim & Obs & Diff & Sim & Obs & Diff $(\%)$ \\
\hline KT & 17 & 18 & -4.5 & 14 & 14 & 3.9 & 3.2 & 4.5 & -29.8 \\
\hline DS & 20 & 22 & -8.3 & 18 & 18 & -0.7 & 2.3 & 4.0 & -41.7 \\
\hline $\mathrm{BP}$ & 22 & 20 & +5.8 & 18 & 17 & 9.5 & 3.3 & 3.7 & -11.1 \\
\hline $\mathrm{BS}$ & 20 & 19 & +3.4 & 16 & 15 & 2.3 & 3.7 & 3.5 & +8.3 \\
\hline BB & 22 & 20 & +7.9 & 14 & 14 & 1.3 & 8.0 & 6.6 & +21.4 \\
\hline GR & 33 & 32 & +5.1 & 26 & 26 & -2.0 & 7.8 & 6.1 & +28.8 \\
\hline GF & 25 & 25 & +1.4 & 19 & 20 & -3.1 & 5.7 & 4.7 & +20.8 \\
\hline EBS & 22 & 20 & +5.0 & 18 & 16 & 7.3 & 3.9 & 4.0 & -2.5 \\
\hline
\end{tabular}

Table 2 Average simulated and observed pelagic $\mathrm{P}(\mu \mathrm{M})$ in 1980-2014, as well as the difference between simulated and observed concentrations calculated as $100 \times(\mathrm{sim}-\mathrm{obs}) / \mathrm{obs}(\%)$ (basins according to Fig. 1)

\begin{tabular}{|c|c|c|c|c|c|c|c|c|c|}
\hline & \multicolumn{3}{|l|}{ TP } & \multicolumn{3}{|l|}{ TOP } & \multicolumn{3}{|l|}{ DIP } \\
\hline & Sim & Obs & Diff $(\%)$ & Sim & Obs & Diff & Sim & Obs & $\operatorname{Diff}(\%)$ \\
\hline KT & 0.77 & 0.79 & -2.9 & 0.41 & 0.39 & 4.9 & 0.36 & 0.40 & -10.4 \\
\hline DS & 0.79 & 0.96 & -17.8 & 0.45 & 0.52 & -13.7 & 0.34 & 0.44 & -22.7 \\
\hline $\mathrm{BP}$ & 1.17 & 1.21 & -3.0 & 0.32 & 0.31 & 6.2 & 0.85 & 0.90 & -6.2 \\
\hline $\mathrm{BS}$ & 0.59 & 0.50 & +18.6 & 0.21 & 0.23 & -6.1 & 0.38 & 0.27 & +39.0 \\
\hline BB & 0.22 & 0.21 & +2.7 & 0.12 & 0.16 & -22.8 & 0.10 & 0.05 & +75.5 \\
\hline GR & 0.96 & 0.91 & +5.1 & 0.46 & 0.60 & -23.8 & 0.50 & 0.31 & +61.0 \\
\hline GF & 1.24 & 0.87 & +42.1 & 0.40 & 0.36 & 11.4 & 0.83 & 0.51 & +64.2 \\
\hline EBS & 0.98 & 0.95 & +2.3 & 0.30 & 0.29 & 2.0 & 0.68 & 0.66 & +2.5 \\
\hline
\end{tabular}

higher the fraction of DIC-rich North Sea water. There is in addition a strong influence from riverine DIC (e.g. Thomas and Schneider 1999). For example, although BS, GR, and GF have similar salinities (not shown) the DIC concentrations are completely different because of different properties of the catchment area (limestone rich catchments in the south versus silicate rocks in the north). The TOC concentrations are related both to terrestrial influence and productivity. The lowest average TOC concentrations are found in the entrance area where the riverine influence is least pronounced.

Table 3 Average simulated pelagic $\mathrm{C}(\mu \mathrm{M})$ in 1980-2014

\begin{tabular}{lllr}
\hline & TC & TOC & DIC \\
\hline KT & 2124 & 186 & 1938 \\
DS & 2046 & 283 & 1763 \\
BP & 1959 & 327 & 1632 \\
BS & 1577 & 315 & 1262 \\
BB & 1195 & 332 & 864 \\
GR & 2505 & 502 & 2004 \\
GF & 1838 & 369 & 1469 \\
EBS & 1844 & 326 & 1519 \\
\hline
\end{tabular}

Thus, in the entrance area with high DIC (strong North Sea signal) and low TOC concentrations we find the highest DIC/TC fraction (Table 4).

TC is dominated by DIC in all basins $-82 \%$ on average (Table 4). $\mathrm{N}$ is in contrast dominated by organic $\mathrm{N}$ in all basins; the overall DIN fraction is on average $18 \%$. $\mathrm{P}$ is dominated by DIP $(\sim 69 \%)$, but

Table 4 Simulated versus observed pelagic DIN/TN and DIP/ TP fractions (\%), as well as simulated DIC/TC fractions (\%); average values over the time period 1980-2014

\begin{tabular}{|c|c|c|c|c|c|}
\hline & \multicolumn{2}{|c|}{ DIN/TN } & \multicolumn{2}{|c|}{ DIP/TP } & \multirow{2}{*}{$\begin{array}{l}\text { DIC/TC } \\
\text { Sim. }\end{array}$} \\
\hline & Sim. & Obs. & Sim. & Obs. & \\
\hline KT & 18 & 25 & 47 & 51 & 91 \\
\hline DS & 12 & 18 & 43 & 46 & 86 \\
\hline BP & 15 & 18 & 72 & 75 & 83 \\
\hline BS & 19 & 18 & 64 & 55 & 80 \\
\hline $\mathrm{BB}$ & 37 & 33 & 44 & 26 & 72 \\
\hline GR & 23 & 19 & 52 & 34 & 80 \\
\hline GF & 23 & 19 & 67 & 58 & 80 \\
\hline EBS & 18 & 19 & 69 & 69 & 82 \\
\hline
\end{tabular}


here we find large differences between different basins. The highest DIP fraction $(\sim 72-75 \%)$ is found in BP, whereas in BB the simulated DIP fraction is $44 \%$ (but only $26 \%$ according to observations). Differences between $\mathrm{N}$ and $\mathrm{P}$ are partly a result of redox-sensitive DIN and DIP alterations, but further depend on the fact that riverine organic $\mathrm{P}$ is assumed to be primarily bio-available ( $85 \%$ degradable versus $15 \%$ refractory), while riverine organic $\mathrm{N}$ is assumed to be primarily unavailable for bacterial degradation (30\% degradable versus $70 \%$ refractory; cf. Stepanauskas et al. 2002). Organic carbon supplied from land and by atmospheric depositions has been assumed to be on average separated into $40 \%$ degradable and $60 \%$ refractory matter (Gustafsson et al. 2014a) (see further below). The fact that the overall simulated TON concentration in the system is overestimated could imply that the prescribed degradable fraction of organic $\mathrm{N}$ in land loads is too low.

Overall we find a close agreement between simulated and observed N:P ratios for total, organic, and inorganic fractions (Table 5), although simulated DIN:DIP ratios are lower than the observed values in all basins. For the entire system, the average simulated pelagic molar C:N:P-ratios are: TC:TN:TP $=1900$ : 22:1; TOC:TON:TOP = 1097:59:1; DIC:DIN:DIP = 2262:5.7:1 (Table 5). There are considerable basinwise differences. For example, in BB we find an average DIC:DIN:DIP ratio of 9284:86:1, whereas in BP the ratio is 1948:3.9:1. The high DIC:DIP and DIN:DIP ratios in BB can be explained by a highly efficient $\mathrm{P}$ sequestration in this basin, resulting both from high oxygen concentration and low salinity. In $\mathrm{BP}$ on the other hand, DIC:DIP and DIN:DIP ratios are considerably lower than in BB because of widespread oxygen deficiency that impedes $\mathrm{P}$ retention in the sediments (Table 5; cf. Conley et al. 2002).

Simulations are biased to some degree because of knowledge gaps in the parametrizations of processes. These gaps refer for example to lateral transports of material along bottoms and further the benthic cycling of carbon and nutrients-in particular the coulped iron-sulfur-phosphorus cycling in the sediments which cannot be resolved by the model. It is also known that the model in cases tends to underutilize available nutrients and underestimate primary production compared to the available observations. Many of these issues have been discussed in depth by Savchuk et al. (2012). However, basin-average nutrient concentrations based on observations can be biased depending on the coverage and distribution (temporal and spatial) of the oceanographic stations employed to calculate the mean concentrations. This means that the values based on observations do not by default provide the best possible representation of basin-average pools and concentrations. There is nonetheless a reasonable agreement between pools and concentrations according to model calculations and reconstructed from observations, respectively.

Constant ratios for degradable versus refractory fractions are of course simplifications; in the real Baltic Sea we would expect different ratios in different parts of the system and during different time periods depending on the properties of the catchment areasorganic material in rivers that drain areas dominated by agriculture in the Danish Straits should for example be more easily degradable than organic matter in forest streams of the Bothnian Bay (cf. Savchuk and Wulff 2009; Williams et al. 2010). On top of that, refractory material exposed to sunlight can be phototransformed
Table 5 Average pelagic $\mathrm{C}: \mathrm{P}$ (simulated) and N:P molar ratios (simulated/ observed) in 1980-2014

\begin{tabular}{lllllll}
\hline & $\begin{array}{l}\text { TC:TP } \\
\text { Sim. }\end{array}$ & $\begin{array}{l}\text { TN:TP } \\
\text { Sim./obs. }\end{array}$ & $\begin{array}{l}\text { TOC:TOP } \\
\text { Sim. }\end{array}$ & $\begin{array}{l}\text { TON:TOP } \\
\text { Sim./obs. }\end{array}$ & $\begin{array}{l}\text { DIC:DIP } \\
\text { Sim. }\end{array}$ & $\begin{array}{l}\text { DIN:DIP } \\
\text { Sim./obs. }\end{array}$ \\
\hline KT & 2788 & $23 / 23$ & 467 & $35 / 37$ & 5381 & $8.8 / 11$ \\
DS & 2618 & $25 / 23$ & 637 & $40 / 36$ & 5242 & $6.9 / 9.6$ \\
BP & 1683 & $19 / 17$ & 1013 & $57 / 59$ & 1948 & $3.9 / 4.2$ \\
BS & 2676 & $33 / 39$ & 1500 & $75 / 71$ & 3362 & $10 / 13$ \\
BB & 5561 & $101 / 98$ & 2789 & $115 / 92$ & 9284 & $86 / 131$ \\
GR & 2664 & $36 / 34$ & 1104 & $56 / 44$ & 4187 & $17 / 21$ \\
GF & 1498 & $20 / 29$ & 914 & $48 / 58$ & 1797 & $6.9 / 9.7$ \\
EBS & 1900 & $22 / 22$ & 1097 & $59 / 60$ & 2262 & $5.7 / 6.1$ \\
\hline
\end{tabular}


into labile material, or, on the contrary, labile material may become bleached and then less degradable (Deutsch et al. 2012). Rates of phototransformation processes are however not well described (Keller and Hood 2013) and for that reason poorly constratined in the model.

Marine and terrestrial contributions to DOC in different areas of the Baltic Sea have been estimated based on carbon isotope signatures (Alling et al. 2008; Deutsch et al. 2012). Two model studies (Gustafsson et al. 2014a; Fransner et al. 2016) used these estimates to calibrate sink terms for terrestrial DOC in the system and concluded that the majority $(\sim 60-80 \%)$ of terrestrial DOC must be removed by internal sinks within the Baltic Sea in order to reproduce observed concentrations. The relative importance of the two sink terms (i.e., mineralization in the water column and flocculation followed by sedimentation and burial/ mineralization in the sediments) is however not clear.

Gustafsson et al. (2014a) estimated that $\sim 60 \%$ of the terrestrial DOC supplied to the Baltic Sea is removed from the water column by internal sinks ( $\sim 40 \%$ by mineralization and $\sim 20 \%$ by flocculation and sedimentation), whereas the remaining $\sim 40 \%$ is exported to the North Sea. Recent studies on the bioavailability of terrestrial DOC however indicate that less than $20 \%$ is degraded, at least over time periods of several months (Hoikkala et al. 2015; Kuliński et al. 2016). Given the long residence time in the Baltic Sea and possibly a prolonged exposure to sunlight, refractory DOC fractions may nevertheless eventually be phototransformed into bioavailable forms. It is also possible that the mineralization rate suggested by Gustafsson et al. (2014a) is overestimated, and the flocculation rate on the other hand underestimated. Nevertheless, the rates suggested by Gustafsson et al. (2014a) where calibrated to produce the best fit between simulated and observed concentrations of marine and terrestrial DOC respectively.

\section{Residence times}

The system has not been in steady state under the study period (Gustafsson et al. 2012), which means that estimates of residence times will be biased by accumulation/loss from nutrient pools and thus depend on the time-period chosen. Here the average residence times over the period 1980-2014 have been estimated for simulated TC, TN, and TP in the EBS by dividing average total pool sizes (pelagic + active sediment) by average sink terms (net export, burial, and denitrification) (Table 6).

Because of a strong $\mathrm{P}$ retention in sediments underlying oxic waters, the sediment $\mathrm{P}$ pool exceeds the pelagic pool by a factor two. The retention further results in a very long residence time for $\mathrm{TP}$, almost 50 years-some $50 \%$ longer than the residence time of water and salt (approximately 33 years; Stigebrandt and Gustafsson 2003). N cycling is in contrast largely dominated by a removal through denitrification (main sink term for $\mathrm{N}$ ), which has the effects (i) that sediment and pelagic $\mathrm{N}$ pools are similar, and (ii) that the residence time is comparatively short (less than 10 years). The residence time for TC is somewhere in between those for TN and TP; approximately 38 years. $\mathrm{C}$ assimilation by autotrophs and subsequent removal through sedimentation and burial can be compensated by absorption of atmospheric $\mathrm{CO}_{2}$. Thus, DIC pools are replenished through a net uptake of atmospheric $\mathrm{CO}_{2}$.

Wulff and Stigebrandt (1989) estimated the pelagic residence times to 5.5 and 13.3 years for $\mathrm{TN}$ and $\mathrm{TP}$ respectively by dividing pool sizes (based on winter values in the period 1977-1980) by the sum of advective and biogeochemical sinks. On the other hand, Wulff et al. (2001) and Savchuk (2005) calculated the pelagic residence times of $\mathrm{TN}$ and $\mathrm{TP}$ by dividing pool sizes by external loads: Wulff et al.

Table 6 Simulated average TC, TN, and TP sources and sinks (kton year ${ }^{-1}$ ), pools (kton), and residence times (years) in the Entire Baltic Sea over the period 1980-2014 respectively

\begin{tabular}{llll}
\hline & TC & TN & TP \\
\hline Land loads & 10,646 & 803 & 44.7 \\
Atm. deposition & 429 & 296 & 6.2 \\
$\mathrm{~N}_{2}$ fixation & - & 408 & - \\
Net air-sea $\mathrm{CO}_{2}$ & 3878 & - & - \\
Net export & 13,416 & 198 & 11.5 \\
Burial & 909 & 145 & 31.2 \\
Denitrification & - & 1153 & - \\
Net accumulation & 628 & 10.6 & 8.1 \\
Pelagic pools & 497,503 & 6768 & 678 \\
Sediment pools & 41,654 & 6643 & 1431 \\
Total pools & 539,157 & 13,411 & 2109 \\
Residence times & 37.6 & 9.0 & 49.3 \\
\hline
\end{tabular}

Residence times (years) were estimated by dividing total pool sizes by sink terms 
(2001) estimated the residence times for TN and TP to 5.3 and 11.6 years respectively based on data in the period 1975-1991. Savchuk (2005) estimated the residence times for TN and TP to 4.7 and 14.7 years respectively based on data in the period 1991-1999. Using the latter approach, our model calculations result in pelagic residence times of 6.2 and 13.3 years for TN and TP respectively in the period 1980-2014 (again, the calculated residence times depend on the chosen time period since the system is not in steady state).

\section{Biogeochemical fluxes}

Although N and P loads peaked around 1980 and have since then declined considerably, there are only minor signs of ecosystem recovery because of the poor capacity of sediments to permanently remove $\mathrm{P}$ from the system-particularly during periods characterized by large areas of anoxic sediments (e.g. Conley et al. 2002).

In Table 7, $\mathrm{N}$ and $\mathrm{P}$ fluxes and pools are shown for two different periods; 1981-1990 and 2001-2010. N and $\mathrm{P}$ loads (land loads + atmospheric depositions) are considerably smaller in the latter period: $\mathrm{N}$ loads and $\mathrm{P}$ loads decreased from 1266 to $940 \mathrm{kton} \mathrm{N}$ year $^{-1}$ $(-26 \%)$ and 63.9 to 39.6 kton $\mathrm{P}$ year $^{-1}(-38 \%)$ respectively. The simulated $\mathrm{N}_{2}$ fixation on the other hand increased from $305 \mathrm{kton} \mathrm{N}$ year $^{-1}$ in the $1980 \mathrm{~s}$ to 492 kton $\mathrm{N}_{\text {year }}{ }^{-1}$ in the in the 2000s (61\% increase). Including $\mathrm{N}_{2}$ fixation, the total $\mathrm{N}$ source is only $8.8 \%$ smaller in the 2000s compared to the 1980s. Reductions in loads (particularly P loads) are not generally reflected by reductions in pools. The simulated pelagic
$\mathrm{N}$ and $\mathrm{P}$ pools are in the 2000s 4.7 and $8.2 \%$ larger, respectively than in the 1980 s.

While denitrification and $\mathrm{P}$ sequestration are controlled by oxygen conditions (and in the case of $\mathrm{P}$ sequestration also salinity), the magnitudes of these fluxes largely depend on the magnitude of primary production. Net ecosystem production (NEP) is defined as gross primary production minus respiration of autotrophs and heterotrophs (Woodwell and Whittaker 1968). Here we use NEP in the meaning: $\mathrm{NEP}=$ net primary production (definition according to Platt et al. (1989); i.e., net primary production $=$ gross primary production minus respiration of the autotrophs) minus total regeneration of organic material in the water column (including bacterial degradation of organic material and zooplankton excretion). NEP in $\mathrm{P}$ units is shown in Fig. 3a, whereas the development of anoxic and hypoxic areas are shown in Fig. 3b. Oxygen conditions improve considerably in the late 1980s and early 1990s, and around this period we also find the highest simulated NEP. The corresponding broad peak in net $\mathrm{P}$ accumulation in the sediments is a result of both improved oxygen conditions (i.e., more effective $\mathrm{P}$ retention) and at the same time an increased supply of $\mathrm{P}$ to the sediments because of a high pelagic productivity (and sedimentation). The decline in sediment $\mathrm{P}$ accumulation in the last decade is similarly explained by a slight reduction of NEP in the water column combined with a rather drastic deterioration in oxygen conditions. Changes in the denitrification rate appears to be more strongly coupled to changes in NEP and sedimentation than to changes in the hypoxic area (Fig. 3c). The connection between oxygen conditions and

Table 7 Simulated average TN and TP sources and sinks (kton year ${ }^{-1}$ ), pools (kton) in the Entire Baltic Sea over the periods 1981-1990 and 2001-2010 respectively, as well as the differences between the two periods (\%)

\begin{tabular}{|c|c|c|c|c|c|c|}
\hline & \multicolumn{3}{|l|}{$\mathrm{TN}$} & \multicolumn{3}{|l|}{$\mathrm{TP}$} \\
\hline & 1981-1990 & 2001-2010 & Diff. $(\%)$ & 1981-1990 & 2001-2010 & Diff. (\%) \\
\hline Land load + atm. dep. & 1266 & 940 & -26 & 63.9 & 39.6 & -38 \\
\hline $\mathrm{N}_{2}$ fixation & 305 & 492 & +61 & - & - & - \\
\hline Net export & 210 & 182 & -13 & 13.8 & 10.2 & -26 \\
\hline Burial & 144 & 142 & -1.4 & 30.0 & 31.6 & +5.3 \\
\hline Denitrification & 1119 & 1193 & +6.6 & - & - & - \\
\hline Pelagic pools & 6567 & 6878 & +4.7 & 655 & 709 & +8.2 \\
\hline Sediment pools & 6631 & 6492 & -2.1 & 1378 & 1438 & +4.4 \\
\hline
\end{tabular}


(a)

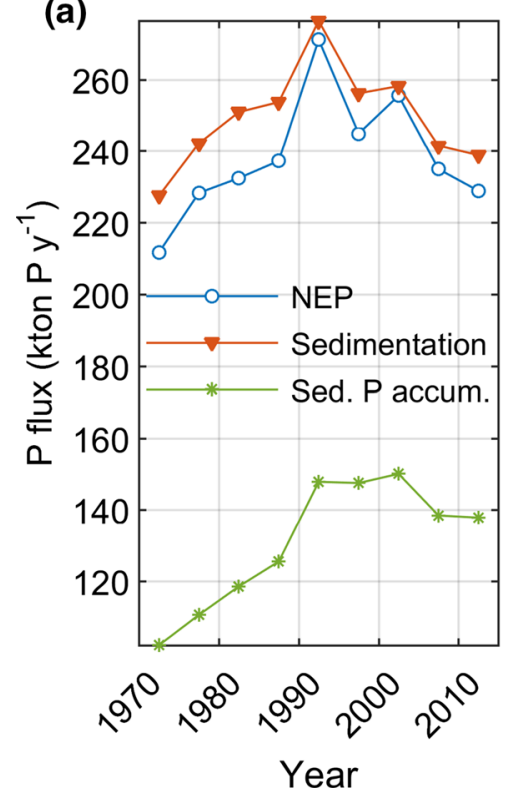

Fig. 3 Simulated 5-year mean rates of a NEP in P units (circles), sedimentation (triangles), and $\mathrm{P}$ accumulation in the sediments (asterisks); b hypoxic (circles) and anoxic (triangles)

denitrification is however not straightforward since denitrification in anoxic water can only continue until all nitrate is consumed. Thus, when the oxygen concentration reaches zero, the denitrification rate can be anything from very high to nonexistent.

Literature estimates of contemporary annual $\mathrm{N}_{2}$ fixation in the Baltic Proper span a wide range; 180-552 kton year $^{-1}$ (Larsson et al. 2001; Wasmund et al. 2001, 2005; Rolff et al. 2007; Savchuk and Wulff 2009; Schneider et al. 2009). Our simulated average $\mathrm{N}_{2}$ fixation rate in 1980-2014 is $408 \pm 130$ kton $\mathrm{N}$ year $^{-1}$ in the EBS (Table 6). This means that $\mathrm{N}_{2}$ fixation in the model on average accounts for $27 \%$ of the total external $\mathrm{N}$ sources. Denitrification is by far the most important sink term for TN according to our calculations. As compiled by Savchuk and Wulff (2009), earlier reported estimates of denitrification rates in different areas of the Baltic Sea can vary quite considerably. These matters will not be discussed in any detail in the present study, instead we choose to highlight a few recent estimates: Noffke et al. (2016) estimated the benthic denitrification rate in the Baltic Proper to $\sim 0.43 \mathrm{mmol} \mathrm{m}^{-2} \mathrm{day}^{-1}$, or some $500 \mathrm{kton}$ year $^{-1}$, while Deutsch et al. (2010) estimated the benthic denitrification rate in the EBS to be in a range 426-652 kton year ${ }^{-1}$. Dalsgaard et al. (2013) (c)

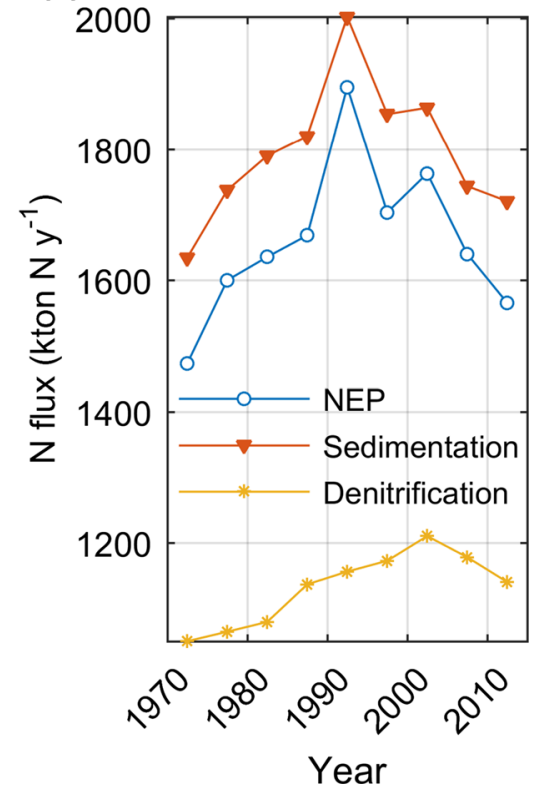

area; c NEP in N units (circles), sedimentation (triangles), and denitrification (asterisks) for the entire Baltic Sea

estimated that pelagic denitrification in the Baltic Proper amounts to $132-547 \mathrm{kton}_{\text {year }}{ }^{-1}$. Our simulated average total denitrification rate (benthic + pelagic) in the EBS in 1980-2014 is $1153 \pm 59.5$ kton $\mathrm{N}$ year ${ }^{-1}$ (Table 6) $(1048 \pm 73.0$ kton $\mathrm{N}_{\text {year }}{ }^{-1}$ in the sediments and $105 \pm 54$ kton $\mathrm{N}$ year $^{-1}$ in the water column respectively). For comparison the TN source from land loads and atmospheric depositions (not including $\mathrm{N}_{2}$ fixation) combined amounts to $1099 \pm 161$ kton $\mathrm{N}_{\text {year }}{ }^{-1}$.

Budget calculations

Average TC, TN, and TP budgets for the period 1980-2014 are presented in Figs. 4, 5 and 6. The budgets include land loads, atmospheric loads (including deposition, $\mathrm{N}_{2}$ fixation by cyanobacteria, and absorption of atmospheric $\mathrm{CO}_{2}$ ), net transports between basins, burial, denitrification, and further both pelagic pools and the pools in the active sediment. The corresponding overall fluxes and pools are presented in Table 6. Land loads are the largest sources of TC, TN, and TP (on average 71, 53, and $88 \%$ respectively of total sources). For TC there is also a large net uptake of atmospheric $\mathrm{CO}_{2}(26 \%)$, and for TN there are large contributions from both 
atmospheric depositions (20\%) and $\mathrm{N}_{2}$ fixation by diazotrophic cyanobacteria (27\%). Denitrification and burial are responsible for approximately $87 \%$ of the total $\mathrm{N}$ removal, while the remaining $13 \%$ is exported to the North Sea. $\mathrm{P}$ sinks are dominated by burial (73\%) while $\mathrm{C}$ removal in contrast is largely dominated by export (94\%). For TC and TN we find a general outward transport, i.e., a net transport from the gulfs to BP and further to the entrance area and out of the system (Figs. 4, 5). There is in contrast a net TP transport from BP to $\mathrm{BS}$ and further from $\mathrm{BS}$ to $\mathrm{BB}$ (Fig. 6).

Temporal development for source and sink terms of total, organic, and inorganic $\mathrm{C}, \mathrm{N}$, and $\mathrm{P}$ are indicated in Figs. 7, 8 and 9. In addition to the total $\mathrm{C}, \mathrm{N}$, and $\mathrm{P}$ source and sink terms in Figs. 4, 5 and 6, these time series also include NEP, sediment mineralization, and net accumulation. The NEP sink terms for DIC, DIN, and DIP exactly correspond to the NEP source terms for TOC, TON, and TOP (Figs. 7, 8, 9). Further, the sediment mineralization terms are equally large sources for DIC, DIN, and DIP as they are sinks for TOC, TON, and TOP. For that reason, NEP and sediment mineralization do not contribute to the TC, $\mathrm{TN}$, and TP budgets.

DIP release from the sediments exceeds TP land loads approximately by a factor five. We nevertheless find that for TP, the overall main balance is that between the land load source and the burial sink. Although the benthic mineralization of organic material produces large fluxes of DIC and DIN to the water column, these are in contrast to the DIP release not an order of magnitude larger than the external sources. The system is ultimately driven by external nutrient loads, but the response to changes in these loads is by no means expected to be linear; changes in nutrient loads not only directly affect the primary productivity, but in addition indirectly through changes in oxygen demand which in turn influences the redox-sensitive $\mathrm{N}$ - and $\mathrm{P}$ cycling.

Although there is a net export of TN and TP out of the Baltic Sea (on average 198 and 11.5 kton year $^{-1}$ respectively; Table 6), there is according to our calculations a net import of both DIN and DIP from the North Sea (on average 24.9 and 1.3 kton year $^{-1}$ respectively). DIC export out of the system (on average $10,120 \mathrm{kton} \mathrm{year}^{-1}$ ) is in contrast the main loss term for TC. In the productive season, DIN and DIP are usually assimilated to depletion in the sunlit layer, while only a small fraction $(\sim 10 \%)$ of the DIC pool is utilized. In terms of $\mathrm{C}: \mathrm{N}: \mathrm{P}$ ratios, the available DIC pool thus by far exceeds what is required by the primary producers. Further, the tendency towards $\mathrm{CO}_{2}$ equilibration between air and surface water means that
Fig. 4 Total carbon budget for the Baltic Sea in 1980-2014. Average pelagic (bold) and benthic (within brackets) pools (kton C), land loads and atmospheric loads (including $\mathrm{C}$ deposition and net air-sea $\mathrm{CO}_{2}$ exchange), net transports, and permanent burial (kton $\mathrm{C}$ year $^{-1}$ )

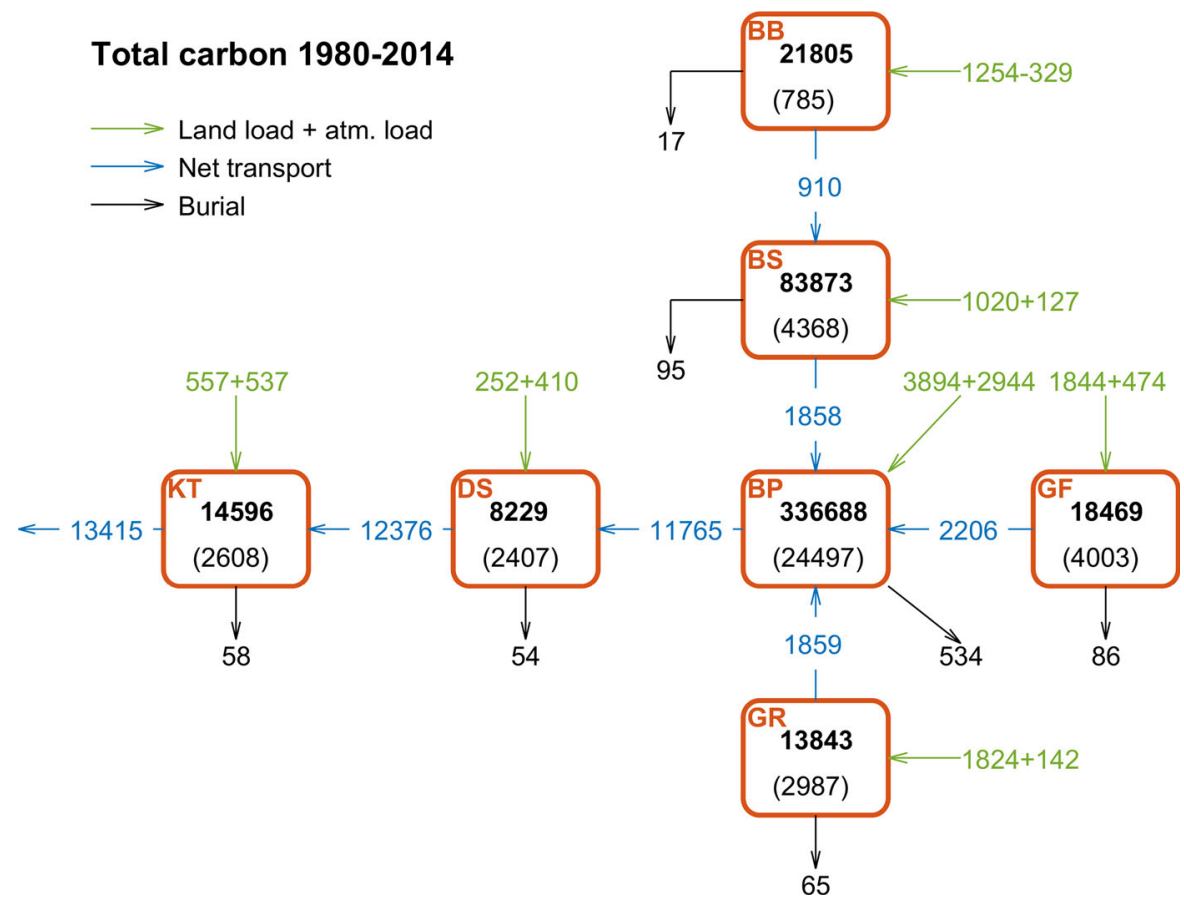


Fig. 5 Total nitrogen budget for the Baltic Sea in 1980-2014. Average pelagic (bold) and benthic (within brackets) pools (kton N), land loads and atmospheric loads (including $\mathrm{N}$ deposition and $\mathrm{N}_{2}$ fixation), net transports, permanent burial and denitrification (kton $\mathrm{N}$ year $^{-1}$ )

Fig. 6 Total phosphorus budget for the Baltic Sea in 1980-2014. Average pelagic (bold) and benthic (within brackets) pools (kton P), land loads and atmospheric loads, net transports, and permanent burial (kton $\mathrm{P}$ year ${ }^{-1}$ )
Total nitrogen 1980-2014
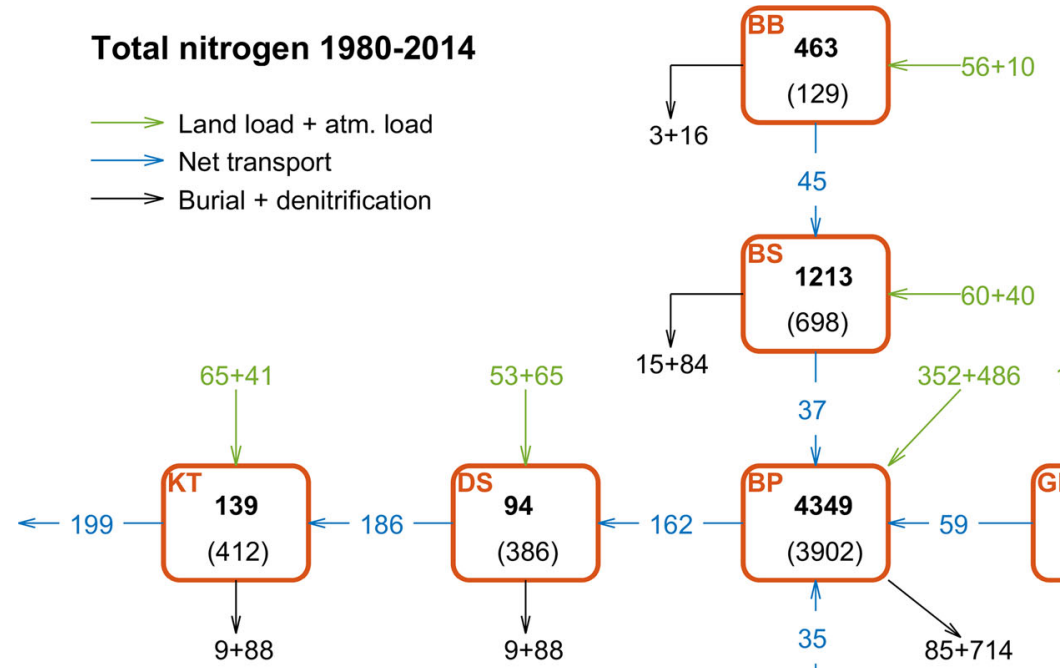

$+84$

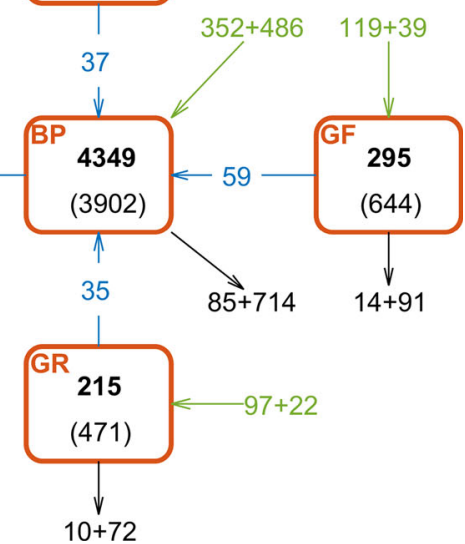

Total phosphorus 1980-2014
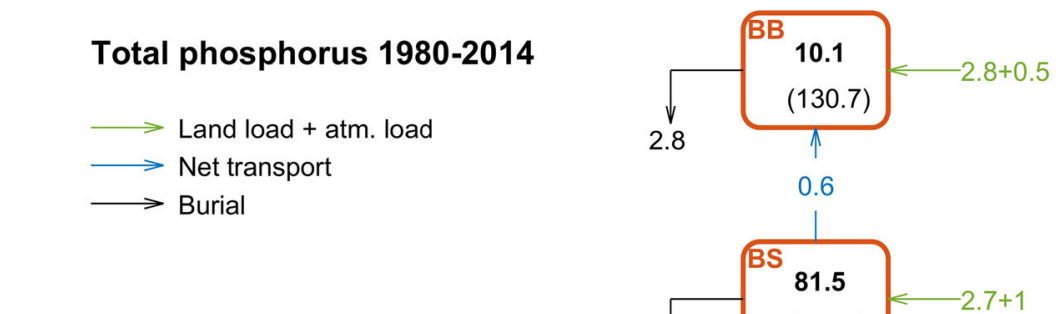
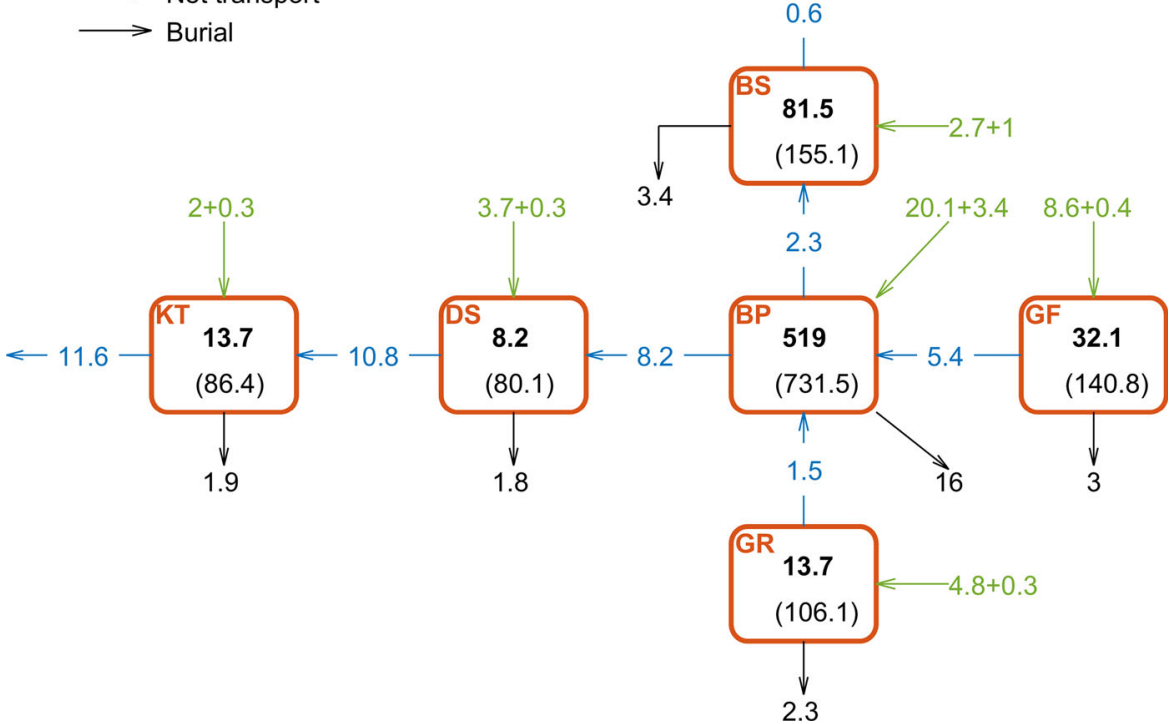

a net $\mathrm{CO}_{2}$ removal by phytoplankton is-albeit sluggishly-replaced through absorption of atmospheric $\mathrm{CO}_{2}$. There are no corresponding processes to refill the pelagic reservoirs of DIN and DIP $\left(\mathrm{N}_{2}\right.$ fixation translates to primary production, not storage replenishment). On the contrary, denitrification and precipitation of $\mathrm{P}$ by iron-humic complexation to some extent limit the replenishment of these pools.

Coastal seas can thus function as effective TN and TP filters in the sense that only minor fractions of the 

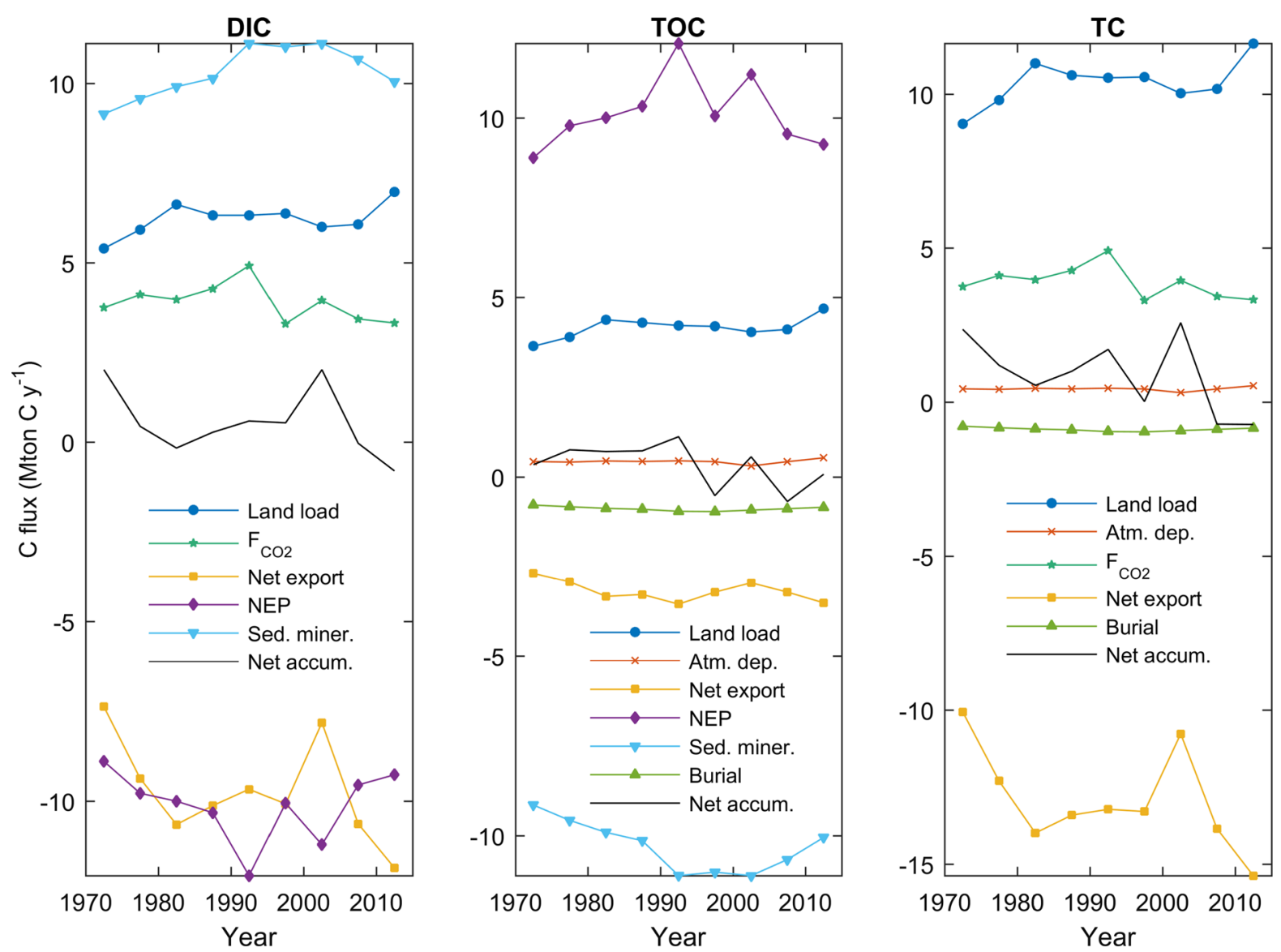

Fig. 7 Simulated 5-year mean source and sink terms for DIC, TOC, and TC in the EBS (Mton $\mathrm{C}_{\text {year }}{ }^{-1}$ ); including land load, air-sea $\mathrm{CO}_{2}$ flux $\left(\mathrm{F}_{\mathrm{CO}_{2}}\right)$, atmospheric deposition, net export, net

external inputs are eventually transported to the open ocean. Such filtering is for reasons discussed above far less efficient for TC. Our calculations imply that the Baltic Sea overall is a net sink for atmospheric $\mathrm{CO}_{2}$. The absorbed atmospheric $\mathrm{CO}_{2}$ replenishes the surface pool of DIC and in extension contributes to the net DIC export out of the system.

\section{Summary and conclusions}

In this study we use an extended version of the BALTSEM model that includes inorganic nutrients, labile and refractory fractions of dissolved organic $\mathrm{C}$, $\mathrm{N}$ and $\mathrm{P}$, particulate organic $\mathrm{C}, \mathrm{N}$, and $\mathrm{P}$ in detritus and plankton, as well as the carbonate system (TA, DIC, $\mathrm{pH}$, and $\mathrm{pCO}_{2}$ ). The model simulation as well as the ecosystem production (NEP), sediment mineralization, burial, and net accumulation

observational data cover a 45-year period (1970-2014), and there is an overall good agreement between simulated nutrient concentration and concentrations based on observations.

We can thus for the first time present a coupled physical-biogeochemical Baltic Sea model that allows simultaneous comparisons between simulated and measured TN and TP concentrations (in addition to DIN and DIP), as well as calculations of the organic, inorganic, and total carbon concentrations. As noted by Wulff and Stigebrandt (1989) in their early estimates of nutrient budgets for the Baltic Sea, budget calculations cannot be considered complete if only the water column is included and not the benthic compartment. By including the active sediment layer in our budget calculations, we have obtained a complete coverage of the $\mathrm{C}, \mathrm{N}$, and $\mathrm{P}$ cycling on a system-scale. In fact, by 


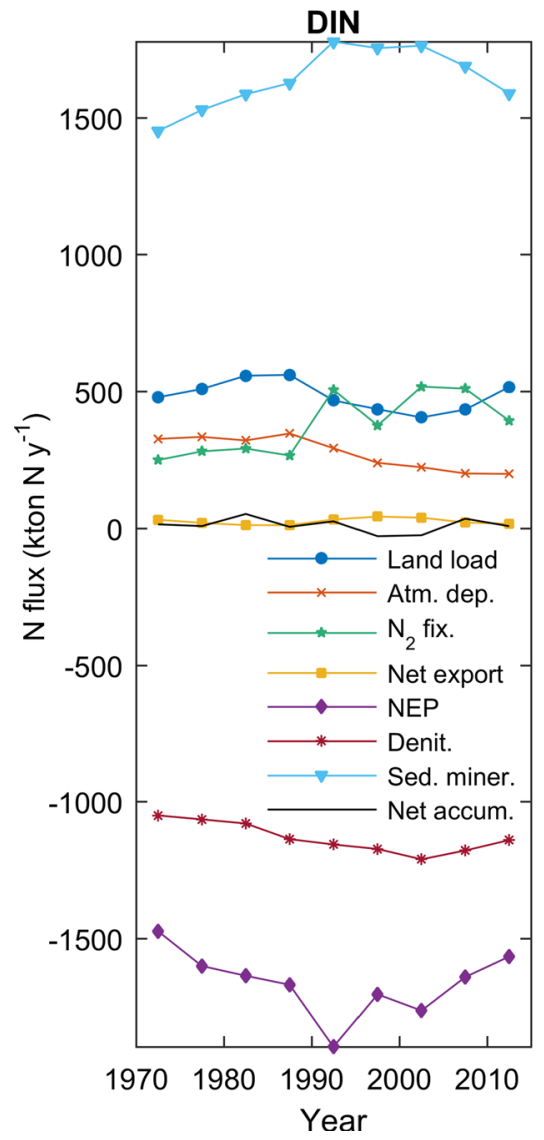

Fig. 8 Simulated 5-year mean source and sink terms for DIN, TON, and TN in the EBS (kton N year ${ }^{-1}$ ); including land load, atmospheric deposition, $\mathrm{N}_{2}$ fixation, net export, net ecosystem

including the sediments, the residence time for $\mathrm{TN}$ approximately doubles while the residence time for TP increases by almost a factor four.

The novelty and progress of the present study in relation to earlier publications can thus be summarized by (i) the inclusion of organic carbon and the carbonate system, (ii) the inclusion of carbon and nutrients temporarily stored in the sediments in our budget calculations, and (iii) the inclusion of both refractory and labile dissolved organic material allowing total $\mathrm{C}, \mathrm{N}$, and $\mathrm{P}$ budgets. Our main findings are summarized below.

- In spite of limitations both in terms of process parameterizations in the model and in terms of spatial and temporal coverage in the observed data, we find an overall reasonable agreement between inorganic and organic $\mathrm{N}$ and $\mathrm{P}$ pools and concentrations, as well as inorganic versus organic

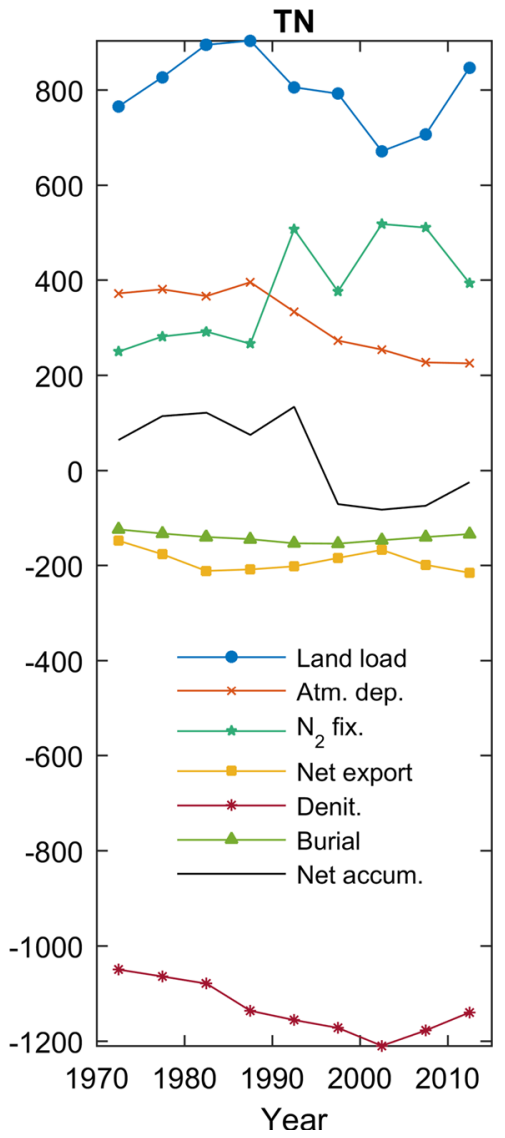

production (NEP), denitrification, sediment mineralization, burial, and net accumulation

fractions obtained from model simulations and reconstructed from observations, respectively.

- Approximate residence times calculated as reservoir sizes divided by permanent sinks are for TC, $\mathrm{TN}$, and TP 38, 9.0, and 49 years respectively (including both pelagic and benthic reservoirs).

- Overall, 82 and 69\% of the pelagic TC and TP pools consist of DIC and DIP respectively. In contrast, only $18 \%$ of the pelagic TN pool consists of DIN.

- $\mathrm{TN}$ and TP sink terms are dominated by internal removal processes (87 and 73\%), whereas TC sinks are almost completely dominated by export out of the system (94\%). The Baltic Sea thus functions as a filter that removes/retains TN and TP, but not TC.

- There is according to our calculations a net import of DIN and DIP from the North Sea (although a net export of TN and TP), but on the contrary a net export of DIC (and TC). 

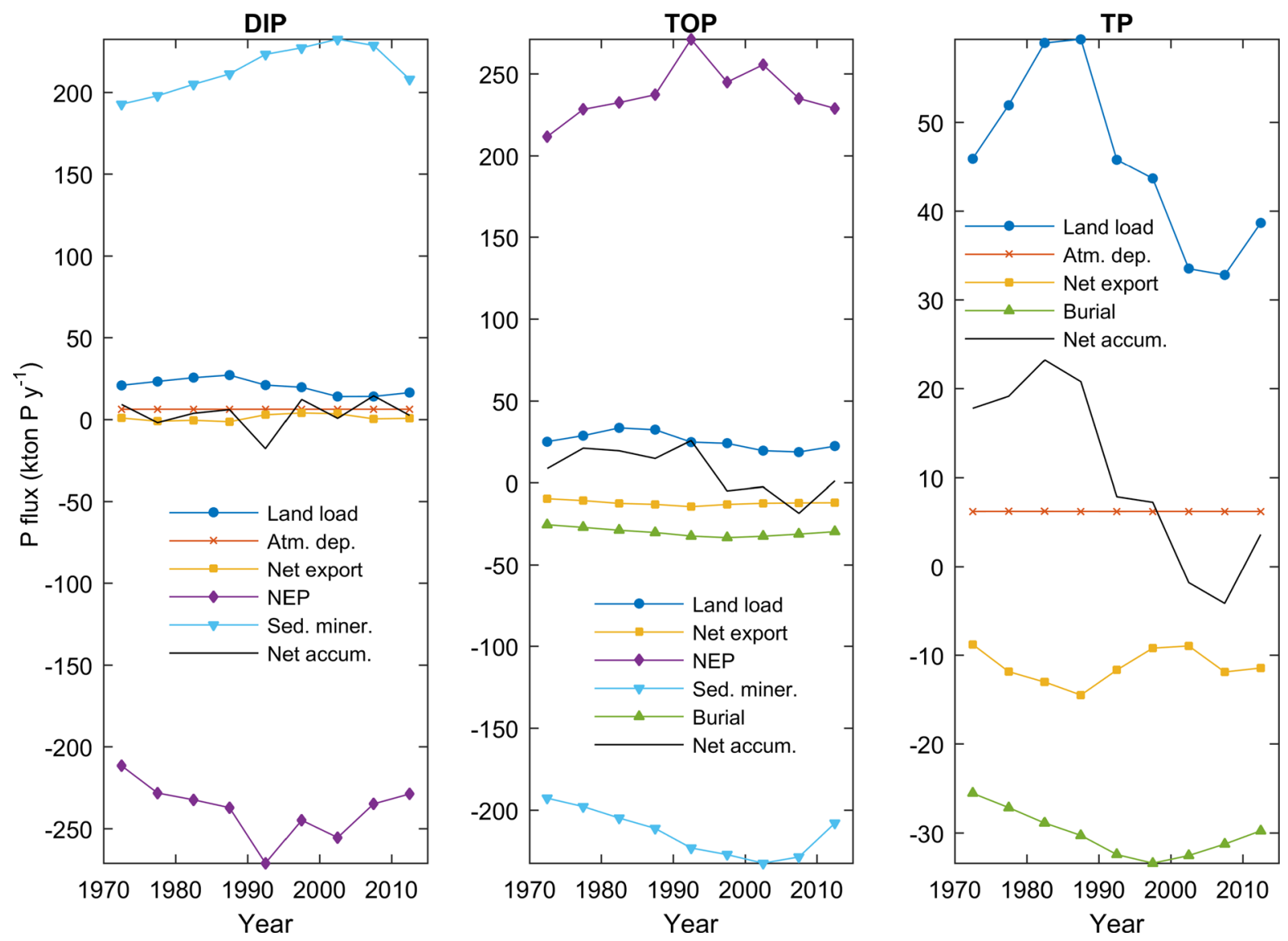

Fig. 9 Simulated 5-year mean source and sink terms for DIP, TOP, and TP in the Entire Baltic Sea (kton P year ${ }^{-1}$ ); including land load, atmospheric deposition, net export, net ecosystem production (NEP), sediment mineralization, burial, and net accumulation

Acknowledgements The Baltic Nest Institute is supported by the Swedish Agency for Marine and Water Management through their Grant 1:11-Measures for marine and water environment. Erik Smedberg is acknowledged for contributions to the artwork. The observational data used in this study have been made available by many individuals, institutions, and agencies, whose contribution is very much appreciated (http:// nest.su.se/bed/ACKNOWLE.shtml).

Open Access This article is distributed under the terms of the Creative Commons Attribution 4.0 International License (http:// creativecommons.org/licenses/by/4.0/), which permits unrestricted use, distribution, and reproduction in any medium, provided you give appropriate credit to the original author(s) and the source, provide a link to the Creative Commons license, and indicate if changes were made.

\section{References}

Alling V, Humborg C, Mörth C-M, Rahm L, Pollehne F (2008) Tracing terrestrial organic matter by $\delta^{34} \mathrm{~S}$ and $\delta^{13} \mathrm{C}$ signatures in a subarctic estuary. Limnol Oceanogr 53:2594-2602. doi:10.4319/lo.2008.53.6.2594

Anttila P, Paatero P, Tapper U, Järvinen O (1995) Source identification of bulk wet deposition in Finland by positive matrix factorization. Atmos Environ 29:1705-1718. doi:10.1016/1352-2310(94)00367-T

Bonaglia S, Klawonn I, De Brabandere L, Deutsch B, Thamdrup B, Brüchert V (2016) Denitrification and DNRA at the Baltic Sea oxic-anoxic interface: substrate spectrum and kinetics. Limnol Oceanogr 61:1900-1915. doi:10.1002/ lno. 10343

Conley DJ, Humborg C, Rahm L, Savchuk OP, Wulff F (2002) Hypoxia in the Baltic Sea and basin-scale changes in phosphorus biogeochemistry. Environ Sci Tech 36:5315-5320. doi:10.1021/es025763w

Conley DJ, Paerl HW, Howarth RW et al (2009) Controlling eutrophication: nitrogen and phosphorus. Science 323:1014-1015. doi:10.1126/science.1167755

Dalsgaard T, De Brabandere L, Hall POJ (2013) Denitrification in the water column of the central Baltic Sea. Geochim Cosmochim Acta 106:247-260. doi:10.1016/j.gca.2012. 12.038

Deutsch B, Forster S, Wilhelm M, Dippner JW, Voss M (2010) Denitrification in sediments as a major nitrogen sink in the 
Baltic Sea: an extrapolation using sediment characteristics. Biogeosciences 7:3259-3271. doi:10.5194/bg-7-32592010

Deutsch B, Alling V, Humborg C, Korth F, Mörth CM (2012) Tracing inputs of terrestrial high molecular weight dissolved organic matter within the Baltic Sea ecosystem. Biogeosciences 9:4465-4475. doi:10.5194/bg-9-4465-2012

Diaz RJ, Rosenberg R (2008) Spreading dead zones and consequences for marine ecosystems. Science 321:926-929. doi:10.1126/science. 1156401

Fransner F, Nycander J, Mörth C-M et al (2016) Tracing terrestrial DOC in the Baltic Sea-a 3-D model study. Global Biogeochem Cycle 30:134-148. doi:10.1002/2014GB00 5078

Gustafsson BG (2000) Time-dependent modeling of the Baltic entrance area. 1. Quantification of circulation and residence times in the Kattegat and the straits of the Baltic sill. Estuaries 23:231-252

Gustafsson BG (2003) A time-dependent coupled-basin model of the Baltic Sea. C47. Earth Sciences Centre, Göteborg University, Göteborg

Gustafsson BG, Schenk F, Blenckner T et al (2012) Reconstructing the development of Baltic Sea eutrophication 1850-2006. Ambio 41:534-548. doi:10.1007/s13280-0120318-x

Gustafsson E, Deutsch B, Gustafsson BG, Humborg C, Mörth C-M (2014a) Carbon cycling in the Baltic Sea-the fate of allochthonous organic carbon and its impact on air-sea $\mathrm{CO}_{2}$ exchange. J Mar Syst 129:289-302. doi:10.1016/j. jmarsys.2013.07.005

Gustafsson E, Wällstedt T, Humborg C, Mörth C-M, Gustafsson BG (2014b) External total alkalinity loads versus internal generation: the influence of nonriverine alkalinity sources in the Baltic Sea. Glob Biogeochem Cycle 28:1358-1370. doi:10.1002/2014GB004888

Gustafsson E, Omstedt A, Gustafsson BG (2015) The air-water $\mathrm{CO}_{2}$ exchange of a coastal sea-a sensitivity study on factors that influence the absorption and outgassing of $\mathrm{CO}_{2}$ in the Baltic Sea. J Geophys Res 120:5342-5357. doi:10. 1002/2015JC010832

HELCOM (2013) Review of the fifth Baltic Sea pollution load compilation for the 2013 HELCOM Ministerial Meeting, Balt. Sea Environ. Proc., vol 141

Hoikkala L, Kortelainen P, Soinne H, Kuosa H (2015) Dissolved organic matter in the Baltic Sea. J Mar Syst 142:47-61. doi:10.1016/j.jmarsys.2014.10.005

Keller DP, Hood RR (2013) Comparative simulations of dissolved organic matter cycling in idealized oceanic, coastal, and estuarine surface waters. J Mar Syst 109-110:109-128. doi:10.1016/j.jmarsys.2012.01.002

Kuliński K, Hammer K, Schneider B, Schulz-Bull D (2016) Remineralization of terrestrial dissolved organic carbon in the Baltic Sea. Mar Chem 181:10-17. doi:10.1016/j. marchem.2016.03.002

Larsson U, Hajdu S, Walve J, Elmgren R (2001) Baltic Sea nitrogen fixation estimated from the summer increase in upper mixed layer total nitrogen. Limnol Oceanogr 46:811-820. doi:10.4319/lo.2001.46.4.0811

Nixon SW (1995) Coastal marine eutrophication: a definition, social causes, and future concerns. Ophelia 41:199-219. doi:10.1080/00785236.1995.10422044
Noffke A, Sommer S, Dale AW, Hall POJ, Pfannkuche O (2016) Benthic nutrient fluxes in the Eastern Gotland Basin (Baltic Sea) with particular focus on microbial mat ecosystems. J Mar Syst 158:1-12. doi:10.1016/j.jmarsys.2016.01.007

Platt T, Harrison WG, Lewis MR, Li WKW, Sathyendranath S, Smith RE, Vezina AF (1989) Biological production of the oceans: the case for a consensus. Mar Ecol Prog Ser 52:77-88

Rolff C, Almesjö L, Elmgren R (2007) Nitrogen fixation and abundance of the diazotrophic cyanobacterium Aphanizomenon sp. in the Baltic Proper. Mar Ecol Prog Ser 332: $107-118$

Savchuk OP (1986) The study of the Baltic Sea eutrophication problems with the aid of simulation models. Baltic Sea Environ Proc 19:51-61

Savchuk OP (2002) Nutrient biogeochemical cycles in the Gulf of Riga: scaling up field studies with a mathematical model. J Mar Syst 32:253-280. doi:10.1016/S09247963(02)00039-8

Savchuk OP (2005) Resolving the Baltic Sea into seven subbasins: N and P budgets for 1991-1999. J Mar Syst 56:1-15. doi:10.1016/j.jmarsys.2004.08.005

Savchuk OP (2010) Large-scale dynamics of hypoxia in the Baltic Sea. Large-scale dynamics of hypoxia in the Baltic Sea. In: Yakushev E (ed) Chemical structure of pelagic redox interfaces: observation and modelling. Springer, Berlin

Savchuk OP, Wulff F (2007) Modeling the Baltic Sea eutrophication in a decision support system. Ambio 36:141-148. doi:10.1579/0044-7447(2007)36[141:MTBSEI]2.0.CO;2

Savchuk OP, Wulff F (2009) Long-term modeling of large-scale nutrient cycles in the entire Baltic Sea. Hydrobiologia 629:209-224. doi:10.1007/s10750-009-9775-z

Savchuk OP, Gustafsson BG, Müller-Karulis B (2012) BALTSEM-a marine model for the decision support within the Baltic Sea Region, BNI Technical Report No 7

Schneider B, Kaitala S, Raateoja M, Sadkowiak B (2009) A nitrogen fixation estimate for the Baltic Sea based on continuous $\mathrm{pCO}_{2}$ measurements on a cargo ship and total nitrogen data. Cont Shelf Res 29:1535-1540. doi:10.1016/ j.csr.2009.04.001

Sokolov A, Andrejev AA, Wulff F, Rodriguez-Medina M (1997) The Data Assimilation System for data analysis in the Baltic Sea. Contrib Systems Ecol 3, Stockholm University, Stockholm, Sweden

Stepanauskas R, Jørgensen NOG, Eigaard OR, Zvikas A, Tranvik LJ, Leonardson L (2002) Summer inputs of riverine nutrients to the Baltic Sea: bioavailability and eutrophication relevance. Ecol Monogr 72:579-597. doi:10.1890/0012-9615(2002)072[0579:SIORNT]2.0. $\mathrm{CO} ; 2$

Stigebrandt A, Gustafsson BG (2003) Response of the Baltic Sea to climate change - theory and observations. J Sea Res 49:243-256. doi:10.1016/S1385-1101(03)00021-2

Thomas H, Schneider B (1999) The seasonal cycle of carbon dioxide in Baltic Sea surface waters. J Mar Syst 22:53-67. doi:10.1016/S0924-7963(99)00030-5

Thomas H, Schiettecatte LS, Suykens K et al (2009) Enhanced ocean carbon storage from anaerobic alkalinity generation in coastal sediments. Biogeosciences 6:267-274. doi:10. 5194/bg-6-267-2009 
Vahtera E, Conley DJ, Gustafsson BG et al (2007) Internal ecosystem feedbacks enhance nitrogen-fixing cyanobacteria blooms and complicate management in the Baltic Sea. Ambio 36:186-194. doi:10.1579/0044-7447(2007)36[186: IEFENC]2.0.CO;2

Wanninkhof R (1992) Relationship between wind speed and gas exchange over the ocean. J Geophys Res 97:7373-7382. doi:10.1029/92JC00188

Wanninkhof R, Asher WE, Ho DT, Sweeney C, McGillis WR (2009) Advances in quantifying air-sea gas exchange and environmental forcing. Annu Rev Mar Sci 1:213-244. doi:10.1146/annurev.marine.010908.163742

Wasmund N, Voss M, Lochte K (2001) Evidence of nitrogen fixation by non-heterocystous cyanobacteria in the Baltic Sea and re-calculation of a budget of nitrogen fixation. Mar Ecol Prog Ser 214:1-14

Wasmund N, Nausch G, Schneider B, Nagel K, Voss Maren (2005) Comparison of nitrogen fixation rates determined with different methods: a study in the Baltic Proper. Mar Ecol Prog Ser 297:23-31

Weiss RF (1974) Carbon dioxide in water and seawater: the solubility of a non-ideal gas. Mar Chem 2:203-215. doi:10. 1016/0304-4203(74)90015-2
Weiss A, Kuss J, Peters G, Schneider B (2007) Evaluating transfer velocity-wind speed relationship using a long-term series of direct eddy correlation $\mathrm{CO}_{2}$ flux measurements. J Mar Syst 66:130-139. doi:10.1016/j.jmarsys.2006.04. 011

Williams CJ, Yamashita Y, Wilson HF, Jaffé R, Xenopoulos MA (2010) Unraveling the role of land use and microbial activity in shaping dissolved organic matter characteristics in stream ecosystems. Limnol Oceanogr 55:1159-1171. doi:10.4319/lo.2010.55.3.1159

Woodwell GM, Whittaker RH (1968) Primary production in terrestrial ecosystems. Am Zool 8:19-30. doi:10.1093/icb/ 8.1 .19

Wulff F, Stigebrandt A (1989) A time-dependent budget model for nutrients in the Baltic Sea. Global Biogeochem Cy 3:63-78. doi:10.1029/GB003i001p00063

Wulff F, Rahm L, Hallin A-K, Sandberg J (2001) A nutrient budget model of the Baltic Sea. In: Wulff F, Rahm L, Larsson P (eds) A systems analysis of the Baltic Sea. Springer, Berlin, pp 353-372 